\title{
PENGEMBANGAN MODUL PEMBELAJARAN FISIKA BERBASIS KONTEKSTUAL PADA POKOK BAHASAN PEMANASAN GLOBAL UNTUK SISWA SMA
}

\author{
${ }^{1)}$ Nala Kurinta ${ }^{2)}$ Singgih Bektiarso ${ }^{2)}$ Maryani \\ 1) Program Studi pendidikan Fisika FKIP Universitas Jember \\ Email: nalakurinta12@gmail.com
}

\begin{abstract}
The purpose of this research was to analyze the validity and the practicality of the contextual-based physics learning module on the subject of global warming for students high school. Type of this research was research and development $(R \& D)$. The development model used refers to the Nieeven (2006) model which includes 3 stages, namely 1) preliminary research, 2) prototyping stage, 3) assessment stage. Data collection techniques used are interviews and literature study. The data analysis used is expert validation and practicality data analysis. The results showed that: 1) expert validity was 3.77 with very valid criteria and with a reliability coefficient of $95 \%$. While user validation shows very valid criteria with user validity results of 3.78 and with a reliability coefficient of 100\%. Thus, this contextual-based physics module can be used as teaching material on global warming material. 2) The effectiveness of the calculated pretest and posttest results obtained an $N$-gain score of 0.79 which is included in the high category. The contextual-based physics learning module on the subject of global warming that was developed has effective criteria in improving student learning outcomes at SMAN 2 Jember.
\end{abstract}

Key word: Contextual Module, Effectivity, Global Warming

\section{PENDAHULUAN}

Pembelajaran fisika memerlukan pemahaman konsep-konsep yang sudah ada dalam teori agar siswa dapat memecahkan masalah yang berkaitan dengan fenomena fisika yang ada di sekitarnya. Ada berbagai cara untuk mengatasi masalah yang terkait dengan pemahaman konsep fisika. Salah satunya adalah dengan membuat perbandingan langsung dengan fenomena fisika yang terjadi di lingkungan. Sehingga siswa tidak perlu membayangkan bahwa mereka terkadang tidak mengerti secara detail. Oleh karena itu, proses konstruksi konsep fisika lebih sederhana, karena pengetahuan merupakan hasil konstruksi manusia melalui interaksi objek, fenomena, pengalaman, dan lingkungannya. Atas dasar ini, guru fisika membutuhkan bahan ajar yang dapat menggabungkan konsep teoritis dengan fenomena yang terjadi di lingkungan sekitar untuk pembelajaran, sehingga siswa dapat memahami apa yang terjadi di lingkungan sekitar secara teoritis dan praktis. Guru harus memiliki kepekaan terhadap fenomena baru berkaitan dengan ilmu fisika dengan cara memperoleh informasi terkini berdasarkan pada temuan dari penelitian baik dari jurnal maupun media lainnya yang credibel. Berkaitan dengan hal tersebut, salahsatu metode belajar yang dapat diberikan oleh guru kepada siswa adalah paduan antara materi dengan paduan teoritis dan praktik. 
Pembelajaran berbasis kontekstual adalah suatu kegiatan pembelajaran yang mengintegrasikan materi yang telah dipelajari dengan kehidupan sehari-hari. Pembelajaran berbasis kontekstual mampu memberikan paradigma baru untuk siswa dalam proses pemecahan masalah, sebab dengan mencari alternatif dari suatu permasalahan siswa akan lebih cepat berkembang secara baik dan utuh, bukan hanya secara intelektual, tetapi juga dari segi mental dan emosionalnya (Hamruni, 2012: 135). Salah satu hal yang dapat digunakan sebagai penunjang berhasilnya proses pembelajaran kontekstual di sekolah yaitu dengan ketersediaannya suatu bahan ajar. Salah satu contoh bahan ajar yang bisa dijadikan sebagai penunjang kegiatan pembelajaran kontekstual adalah modul pembelajaran. Menurut Asyhar (2011: 155), modul adalah sebuah bahan ajar yang berbasis cetakan yang telah dirancang untuk proses pembelajaran yang dapat digunakan mandiri oleh siswa karena itu dalam modul tersebut dilengkapi dengan adanya petunjuk untuk belajar.

Modul merupakan dokumen yang disusun berdasarkan sistematika yang didalamnya mencakup konten atau isi, metode, dan penilaian atau evaluasi yang dapat digunakan secara mandiri oleh siswa, sehingga siswa dapat melakukan self assessment terhadap capaian dirinya sendiri. Dengan adanya self assessment tersebut maka membentuk karakter siswa menjadi individu yang lebih bertanggung jawab atas tindakannya karena mereka dapat menggunakan kriteria kinerja dari setiap modul yang mereka selesaikan untuk mengontrol hasil belajar. (Setyowati et al. 2013). Bukan hanya sekedar itu saja, modul adalah salah satu media ajar yang telah dikembangkan sedemikian rupa oleh akademisi atau guru, maka apabila proses pembelajaran dengan menggunakan modul akan mengintegrasikan antara materi Fisika dengan kejadian-kejadian dalam kehidupan sehari-hari berpeluang besar dapat terlaksana.

Modul berbasis kontekstual merupakan salah satu bahan ajar yang didalamnya berisi konsep fisika disertai dengan gambar yang dikaitkan dengan fenomena-fenomena dalam kehidupan sehari-hari. Pengembangan modul berbasis kontekstual adalah salah satu cara untuk mengatasi permasalahan siswa terkait pemahaman konsep fisika. Modul berbasis kontekstual siswa tidak perlu membayangkan suatu hal yang terkadang belum mereka pahami secara detail. Sehingga pembelajaran yang sesuai dengan uraian tersebut adalah dengan menggunakan modul berbasis kontekstual sebagai penunjang kegiatan pembelajaran bagi guru dan juga siswa serta sebagai bahan pembelajaran bagi siswa.

Tujuan penelitian ini adalah untuk menganalisis validitas dan kepraktisan modul pembelajaran fisika berbasis kontekstual pokok bahasan pemanasan global untuk siswa SMA.

\section{METODE}

Penelitian ini dilaksanakan di SMAN 2 Jember dengan waktu penelitian dilakukan pada semester genap pelaksanaan pada semester genap siswa kelas XI IPA SMAN 2 Jember tahun ajaran 2019/2020. Jenis penelitian ini adalah penelitian pengembangan (research and development). Subyek penelitian diperoleh dengan menggunakan metode cluster random sampling, pengambilan sampel dalam penelitian ini bukan personal melainkan kelompok atau kelas XI IPA. Desain penelitian yang digunakan dalam penelitian ini adalah penelitian pengembangan dengan mengacu pada Nieeven (2006) yang meliputi 3 tahapan yaitu 1) preliminary research (studi pendahuluan), 2)prototyping stage (tahap perancangan), 3)assesment stage (tahap penilaian). Teknik pengumpulan data yang 
digunakan yaitu wawancara dan studi literatur.

Analisis data yang digunakan adalah validasi ahli dan analisis data kepraktisan. Validasi ahli terbagi menjadi 3 yaitu:

a. Validator

Uji validasi ahli dilkakukan oleh ahli atau pakar di bidang tersebut. Pengembangan modul berbasis kontekstual divalidasi oleh dua dosen pendidikan fisika FKIP Universitas Jember. Validator menilai dan juga memberikan saran untuk dasar perbaikan modul fisika yang telah dikembangkan.

b. Instrumen

Instrumen validitas yaitu instrumen yang digunakan oleh validator untuk menilai kualitas kevalidan dari produk yang dikembangkan. Instrumen penilaian kualitas produk validator meliputi lembar validitas ahli modul fisika.

c. Metode Pengumpulan Data

Kegiatan validasi oleh dosen ahli ketika desain produk telah selesai dilakukan. Dimana data validasi modul pembelajaran fisika berbasis kontekstual pada pokok bahasan pemanasan globalini dikumpulkan dengan memberikan 20 pertanyaan instrumen validasi dan skor penilaian terdiri dari skala 1 hingga 4 yaitu 1: tidak baik; 2: kurang baik; 3: baik; 4: sangat baik.

Analisis data kepraktisan yaitu menggunakan deskriptif kuantitatif. Teknik analisis data ini digunakan untuk mengolah data yang diperoleh melalui angket dalam bentuk deskriptif presentase. Persentase data yang didapat dari angket respon dosen dihitung berdasarkan skala Guttman dengan keterangan sebagai berikut: a. skor 1 pada pilihan "setuju" dengan pernyataan positif atau pilihan "tidak setuju" pada pernyataan negatif, b. skor 0 pada pilihan "tidak setuju" dengan pernyataan positif atau pilihan "setuju" pada pernyataan negatif. Rumus yang digunakan untuk menghitung persentase dari masing-masing aspek adalah sebagai berikut:

$$
N P=\frac{A}{B} \times 100 \%
$$

Keterangan :

$N P=$ nilai persen yang dicari

$A=$ proporsi jumlah siswa yang memilih setuju

$B=$ jumlah siswa

Menurut Arikunto (2010), kriteria respon siswa menurut nilai presentase ditunjukkan pada Tabel 1 berikut:

Tabel 1. Kriteria respon siswa

\begin{tabular}{cc}
\hline $\begin{array}{c}\text { Interval Respon } \\
\text { Siswa }\end{array}$ & Kriteria \\
\hline $80 \%<\mathrm{Na} \leq 100 \%$ & Sangat Positif \\
$60 \%<\mathrm{Na} \leq 80 \%$ & Positif \\
$40 \%<\mathrm{Na} \leq 60 \%$ & Cukup Positif \\
$20 \%<\mathrm{Na} \leq 40 \%$ & Kurang Positif \\
$\mathrm{Na} \leq 20 \%$ & Sangat Kurang Positif \\
\hline
\end{tabular}

Berdasarkan Tabel 1 Hasil yang didapatkan dari data respon ditelaah dengan besarnya percentage of agreement $\geq 61 \%$ maka modul fisika dikategorikan positif (Masruroh dan Listiadi, 2015 : 3). Produk akhir pengembangan ini berupa modul pembelajaran fisika berbasis kontekstual pada pokok bahasan pemanasan globalyang telah diuji coba lapangan skala besar yang telah direvisi berdasarkan masukan validator ahli.

\section{HASIL DAN PEMBAHASAN}

Hasil penelitian berdasarkan tujuan pertama validitas modul pembelajaran fisika berbasis kontekstual pokok bahasan pemanasan global untuk siswa SMA terdapat 3 tahapan yang dilakukan sebagai berikut.

1. Tahap Preliminary Research (Studi Pendahuluan)

Tahap studi pendahuluan ini bertujuan untuk mendapat gambaran awal yang berkaitan dengan pelaksanaan penelitian dan menggabungkan beberapa informasi mengenai kebutuhan dalam pembelajaran di sekolah. Studi pendahuluan ini dilakukan dengan menganalisis suatu permasalahan dengan melaksanakan wawancara terhadap salah 
satu guru fisika di SMAN 2 Jember. SMAN 2 Jember masih menggunakan LKS yang hanya berisi tentang rangkuman materi, sehingga siswa kurang dapat memahami tentang fenomena yang ada disekitar mereka. Tidak adanya ketersediaan bahan ajar fisika yang berupa modul kontekstual, sehingga siswa membutuhkan modul pembelajaran yang materinya dikaitkan dengan kehidupan sehari-hari, supaya siswa mengetahui bahwa disekitar mereka sebenarnya terjadi peristiwa yang tak lepas dari materi fisika. Tahap selanjutnya yaitu mengkaji beberapa teori dan penelitian terdahulu. Kajian literatur yang dilakukan yaitu mengkaji beberapa artikel tentang masalah bahan ajar yang digunakan disekolah dan kurangnya pemahaman konsep pada pokok bahasan pemanasan global pada hasil penelitian yang dilakukan sebelumnya. Serta model pembelajaran kontekstual yang digunakan dalam komponen modul pembelajaran. Sumber rujukan dari peneliti terdahulu dapat dijadikan referensi dalam penelitian pengembangan modul pembelajaran berbasis kontekstual. komponen-komponen dalam penyusunan modul pembelajaran berbasis kontekstual yaitu berupa halaman judu,judul bab, uraian pokok bahasan atau materi, bahan diskusi, latihan, rangkuman, tes formatif, dan daftar pustaka serta halaman sampul belakang luar. Tahapan ini juga dilakukan analisis kebutuhan untuk melihat kurikulum yang digunakan sekolah untuk memenuhi kompetensi yang harus dikuasai dan dimiliki siswa berdasarkan Kompetensi Inti (KI) dan Kompetensi Dasar (KD) Kurikulum 2013 SMA. Dalam penyusunan modul fisika berbasis kontekstual Kompetensi Dasar (KD) yang dibutuhkan adalah KD 3.12 Menganalisis gejala pemanasan global dan dampaknya bagi kehidupan serta lingkungan dan 4.5 mengajukan ide/gagasan penyelesaian masalah gejala pemanasan global dan dampaknya bagi kehidupan serta lingkungan.

\section{Tahap Prototyping Stage (Tahap Perancangan)}

Tahap Prototyping Stage (Tahap Perancangan) dihasilkan draf 1 modul berbasis kontekstual untuk 3 kegiatan pembelajaran yaitu, kegiatan 1) efek rumah kaca dan gas rumah kaca, 2) pemanasan global dan emisi gas rumah kaca, 3) alternatif solusi dan kesepakatan internasional serta tes formatif untuk keseluruhan materi. Draft 2 yaitu produk yang telah dievaluasi dan direvisi. Selanjutnya yaitu nilai yang diperoleh dirujuk pada kriteria validitas untuk mengetahui tingkat validitas dari modul berbasis kontekstual. Rincian skor keseluruhan aspek validasi modul oleh dua validator ahli dapat dilihat pada lampiran dan ringkasan hasil validasinya sebagai berikut.

Tabel 2. Hasil Validasi Ahli

\begin{tabular}{cccccc}
\hline $\begin{array}{c}\text { Skor Rata- } \\
\text { rata } \\
\text { Validator 1 }\end{array}$ & $\begin{array}{c}\text { Skor Rata- } \\
\text { rata } \\
\text { Validator 2 }\end{array}$ & $\begin{array}{c}\text { Skor Rata-Rata } \\
\text { KeduaValidator }\end{array}$ & $\begin{array}{c}\text { Kategori } \\
\text { Validasi }\end{array}$ & $\begin{array}{c}\text { Koefisien } \\
\text { Reliabilitas }\end{array}$ & Reliabilitas \\
\hline 3,60 & 3,95 & 3,77 & Sangat Valid & $95 \%$ & Reliabel \\
\hline
\end{tabular}

Berdasarkan Tabel 2 hasil validasi yang diperoleh kemudian dianalisis untuk menyempurnakan modul berbasis kontekstual sebelum dilakukan uji coba terbatas dan uji coba luas. Skor kevalidan modul dari perhitungan kedua validator ahli menunjukkan skor 3,77 dan termasuk dalam kategori sangat valid. Dengan demikian dapat dikatakan bahwa modul berbasis kontekstual dapat digunakan dalam pembelajaran. Koefisien reliabilitas modul berbasis kontekstual menunjukkan 95\% dan termasuk dalam kategori reliabel. 
Tabel 3. Hasil Validasi Pengguna

\begin{tabular}{cccccc}
\hline $\begin{array}{c}\text { Skor Rata- } \\
\text { rata } \\
\text { Validator } 1\end{array}$ & $\begin{array}{c}\text { Skor Rata- } \\
\text { rata Validator } \\
2\end{array}$ & $\begin{array}{c}\text { Skor Rata-Rata } \\
\text { KeduaValidator }\end{array}$ & $\begin{array}{c}\text { Kategori } \\
\text { Validasi }\end{array}$ & $\begin{array}{c}\text { Koefisien } \\
\text { Reliabilitas }\end{array}$ & Reliabilitas \\
\hline 3,78 & 3,78 & 3,78 & Sangat Valid & $100 \%$ & Reliabel \\
\hline & & & reliabel. Tahap & perancangan yang
\end{tabular}

Berdasarkan Tabel 3 dapat diketahui bahwa kategori validasi pengguna yang diperoleh adalah sangat valid dengan nilai rata-rata dari kedua validator sebesar 3,78. Koefisien reliabilitas modul pembelajaran fisika berbasis kontekstual menunjukkan hasil $100 \%$ dan termasuk dalam kategori selanjutnya yaitu uji coba terbatas, uji coba ini nantinya akan menghasilkan draf II yang sudah direvisi dan siap digunakan dalam proses pembelajaran. Berikut Tabel 4 tentang hasil respon siswa menggunakan uji terbatas.

Tabel 4. Hasil Respon Siswa Uji Terbatas

\begin{tabular}{cccc}
\hline No. & Aspek & Percentage of agreement & Kriteria \\
\hline 1. & Penyajian modul & $100 \%$ & Sangat Positif \\
2. & Kejelasan isi & $95 \%$ & Sangat Positif \\
3. & Ketercapaian tujuan & $90 \%$ & Sangat Positif \\
& Rata-rata & $95 \%$ & Sangat Positif \\
\hline
\end{tabular}

\section{Berdasarkan tabel 4.5 respon siswa dalam mengikuti pembelajaran menggunakan draf I modul fisika berbasis kontekstual memperoleh nilai hasil rata- rata sebesar 95\% yang memenuhi kriteria sangat positif. Oleh karena itu modul ini dapat digunakan untuk uji coba lapangan setelah dilakukan revisi dan mendapatkan draf II.}

Tabel 5 Hasil Rekapitulasi Uji N-Gain

\begin{tabular}{ccccc}
\hline & Pretest & Postest & N-gain & Kriteria \\
\hline Skor tertingi & 75 & 96 & 0.79 & Tinggi \\
Skor terendah & 37 & 50 & & \\
Rata-rata & 27.3 & 85.5 & & \\
\hline
\end{tabular}

Berdasarkan tabel 5 dapat dilihat bahwa hasil tersebut dapat digunakan sebagai dasar dalam menentukan efektifitas modul berbasis kontekstual pada pokok bahasan pemanasan global. Berdasarkan hasil yang didapat dari analisis data nilai rata-rata $\mathrm{N}$-gain diperoleh nilai 0,79 dengan kriteria tinggi. Dengan demikian, pembelajaran fisika dengan menggunakan modul berbasis kontekstual lebih efektif untuk meningatkan hasil belajar siswa kelas XI

\section{Tahap Assesment Stage (Tahap} Penilaian).

Hasil uji coba pada penelitian ini memperoleh data keefektian modul pembelajaran fisika berbasis kontekstual yang diperoleh dari hasil belajar siswa. Berikut ini rincian hasil perhitungan uji Ngain dapat dilihat pada Tabel 5.
MIPA 1 SMAN 2 JEMBER dibandingkan dengan pembelajaran konvensional.

Modul berbasis kontekstual yang telah diuji dilakukan oleh 2 validator ahli. Nilai gabungan dari kedua validator adalah 3,78 dengan kategori sangat valid. Dalam validasi ahli ini terdapat 3 aspek komponen validasi yaitu konstruk, isi dan bahasa.

Validasi dalam komponen konstruk meliputi (1) Kesesuain isi modul dengan Kompetensi Inti (KI) dan Kompetensi Dasar (KD), (2) Kesesuain isi materi dalam modul dengan tujuan pembelajaran, 
(3) Kesesuain isi materi yang terdapat dalam modul dengan tingkat perkembangan siswa, (4) Kejelasan petunjuk dan arahan kegiatan yang disajikan runtut dan jelas sehingga tidak menimbulkan terjadinya kesalahan dalam melakukan kegiatan, (5) Penyajian materi bersifat interaktif dan partisipatif (pada pembelajaran, mengajak siswa aktif) (6) Kesesuaian tingkat kesulitan materi dengan perkembangan siswa, (7) Kesesuaian kalimat dengan tingkat perkembangan siswa, (8) Kebenaran materi dari aspek ilmu (9) Media pembelajaran dilengkapi dengan pertanyaan mendasar (permasalahan) yang mengarahkan siswa untuk menemukan konsep dasar dan (10) Kesesuaian isi soal dengan materi.

Validasi ahli pada bagian ini terdapat beberapa pembaharuan dan penyesuaian kebutuhan. Pembaharuan pada modul berbasis kontekstual untuk pembelajaran fisika mendorong siswa belajar mandiri merupakan suatu hal yang baru karena pada bahan ajar yang sebelumnya masih bergantung dengan penjelasan guru atau pengajar. Komponen kebutuhan sendiri yaitu diperlukan untuk meningkatkan kemandirian dan kreativitas siswa guna mendukung tujuan pendidikan di Indonesia. Validasi ahli pada komponen bahasa meliputi (1) Bahasa yang digunakan dapat memenuhi aspek keterbacaan, (2) Kesesuaian isi dengan kaidah bahasa Indonesia, (3) Kalimat yang digunakan pada modul sederhana dan mudah dipahami, (4) Kejelasan petunjuk dan arahan pada modul, (5) Sifat komunikatif bahasa yang digunakan, (6) Tingkatan bahasa yang digunakan dalam modul sesuai dengan perkembangan kognitif siswa dan (7) Istilah teknis yang digunakan benar.

Berdasakan kriteria penilaian validasi perangkat pembelajaran diperoleh rata-rata dari dua validator ahli sebesar3.77 dengan kriteria sangat valid koeisien reliabilitas sebesar 95\% dan kriteria reliabilitas reliabel. Sehingga mdul berbasis kontekstual untuk pembelajaran fisika pkok bahasan pemanasan global dapat digunakan tanpa revisi.

Selanjutnya modul yang sudah divalidasi oleh validator pengguna, yaitu dua guru bidang studi fisika SMAN 2 Jember. Komponen validasi pengguna dalam pengembangan modul ini meliputi 4 aspek yaitu relevansi, akurasi, keterbacaan dan kebahasan. Analisis data yang diperoleh dari kedua validator pengguna didapatkan bahwa pada aspek relevansi mendapatkan skor rata-rata 3.56 masuk dalam kategori sangat valid, aspek keterbacaan memperoleh skor rata-rata 4 masuk dalam kategori sangat valid, aspek keterbacaan memperoleh skor rata-rata sebesar 3,83 masuk dalam kategori sangat valid dan aspek kebahasaan memperoleh skor rata-rata sebesar 4 masuk dalam kategori sangat valid. Jadi validasi pengguna dalam modul berbasis kontekstual mendapatkan rata-rata sebesar $100 \%$ dan kriteria reliabilitas reliabel. Sehingga dari data validasi penguuna diketahui bahwa modul sudah sesuai harapan dan tidak ada revisi juga dapat digunakan pada proses pembelajaran.

Modul berbasis kontekstual untuk pembelajaran fisika pokok bahasan pemanasan global yang digunakan dalam tahap penilaian atau tahap uji lapangan adalah produk final dari hasil pengembangan yang telah dilaksanakan oleh peneliti. Proses pembelajaran yang dilakukan mengarah pada RPP yang telah dirancang oleh guru dari SMAN 2 Jember. Uji lapangan ini dilakukan dengan melibatkan siswasiswa kelas XI MIPA 1 SMAN 2 Jember, dimana kelas tersebut dalam pelaksanaan pembelajarannya menggunakan modul berbasis kontekstual. Salah satu tujuan dilakukannya uji lapangan ini yaitu untuk mengetahui tingkat keefektivan modul yang dikembangkan oleh peneliti.

Proses pembelajaran dilakukan selama tiga kali pertemuan dalam pembelajaran daring. Pertemuan pertama diawali dengan siswa mengerjakan soal 
pretest yang bertujuan untuk mengetahui kemampuan awal siswa mengenai materi pemanasan global sebelum menggunakan modul. Setelah siswa mengerjakan pretest guru memberikan beberapa contoh fenomena alam yang sesuai dengan subbab. Pada pertemuan kedua dan ketiga guru melanjutkan materi selajutnya sesuai dengan subbab. Dan pada akhir pembelajaran daring yaitu pertemuan ketiga siswa mengerjakan postest yang bertujuan untuk mengetahui tingkat pemahaman siswa setelah melakukan proses pembelajaran.

Dari data yang diperoleh, hasil pretest dan posttes siswa dapat dilihat pada Tabel 4.6. Dari hasil tersebut rata-rata siswa mengalami peningkatan hasil belajar setelah proses pembelajaran. Nilai rata-rata pretest siswa kelas XI MIPA 1 yaitu 27.3dan nilai rata-rata posttest sebesar 85.5. Secara klasikal nilai pretest dan posttestdianalisis menggunakan uji $\mathrm{N}$-gain untuk mengetahui peningkatan hasil belajar siswa ranah kognitif sebelum dan sesudah melakukan proses pembelajaran.

Hasil dari nilai pretest dan posttest selanjutnya dikalkulasi dan diuji untuk melihat keefektivan modul pembelajaran fisika berbasis kontekstual dengan menggunakan $N$-gain. Hasil analisis data nilai ratarata $N$-gaindiperoleh nilai sebesar 0,79. Menurut Hake (1998) berdasarkan Tabel 3.4 kriteria keefektivan nilai $\mathrm{N}$-gain $0,70 \leq \mathrm{n} \leq 1,00$ diinterpretasikan dalam kategori tinggi maka dapat dikatakan bahwa modul pembelajaran fisika berbasis kontekstual dinyatakan sangat efektif. Sehingga modul berbasis kontekstual untuk pembelajaran fisika pokok bahasan pemanasan global dapat mengembangkan kemampuan kognitif siswa, mengembangkan kemampuan konseptual siswa dan membuat siswa lebih aktif dalam pembelajaran, siswa menjadi terbiasa untuk bekerjasama dalam tim serta meningkatkan kreativitas siswa dalam penelitian ilmiah khususnya pada materipemanasan global.
Nilai $N$-gain yang diperoleh sebesar 0,79 dengan kategori tinggi dikarenakan modul berbasis kontekstual memiliki beberapa kelebihan dibandingkan dengan bahan ajar yang digunakan di SMAN 2 Jember. Kelebihan modul yang dikembangnkan ini diantaranya yaitu materi yang disajikan dikaitkan langsung dengan kehidupan sehari-hari sehingga dapat menunjang pemahaman siswa. Selain itu, dengan adanya gambar yang ada dalam modul berbasis kontekstual dapat membuat siswa lebih tertarik untuk mempelajarinya dan mampu membangkitkan motifasi belajar siswa. Hal ini juga dapat dilihat dari hasil angket respon siswa terhadap pembelajaran menggunakan modul berbasis kontekstual yang terdiri dari tiga aspek yaitu penyajian modul, kejelasan isi dan ketercapaian tujuan.

\section{SIMPULAN DAN SARAN}

Berdasarkan hasil penelitian dan pembahasan, dapat diperoleh kesimpulan sebagai berikut: 1) Hasil validitas ahli sebesar 3,77 dengan kriteria sangat valid dan dengan koefisien reliabilitas sebesar $95 \%$. Sedangkan validasi pengguna menunjukkan kriteria sangat valid dengan hasil validitas pengguna sebesar 3,78 dan dengan koefisien reliabilitas sebesar $100 \%$. Dengan demikian, modul fisika berbasis kontekstual ini dapat digunakan sebagai bahan ajar pada materi pemanasan global dan 2) Berdasarkan perhitungan hasil pretest dan posttest yang dikalkulasi memperoleh skor $N$-gain sebesar 0.79 termasuk dalam kategori tinggi. Dengan demikian, modul pembelajaran fisika yang dikembangkan memiliki kriteria efektif dalam meningkatkan hasil belajar siswa SMAN 2 Jember, sehingga layak digunakan sebagai bahan ajar fisika.

Berdasarkan simpulan yang diperoleh, maka diajukan beberapa saran sebagai berikut: 1) Bagi guru, Guru dapat mengembangkan dan menggunakan modul fisika pemanasan global berbasis kkontekstual pada materi lain sesuai 
dengan kebutuhan dan 2) Bagi peneliti lain, pada implementasi modul berbasis kontekstual untuk pembelajaran fisika perlu adanya bimbingan atau pengarahan sebelum pembelajaran dimulai dan peneliti dapat mengembangkan pada materi lain sehigga modul fisika berbasis kontekstual dapat beraneka ragam.

\section{DAFTAR PUSTAKA}

Arikunto, S. 2010. Prosedur Penelitian, Suatu Pendekatan Praktik. Jakarta: Bina Aksara.

Asyhar, R. (2011). Kreatif Mengembangkan Media

Pembelajaran. Jakarta: Gaung Persada (GP) Press.

Hamruni, 2012, Strategi Pembelajaran. Yogyakarta: Insan Madani.

Setyowati, R., Parmin, dan A.

Widiyatmoko.
Pengembangan Modul IPA Berkarakter Peduli Lingkungan Tema Polusi sebagai Bahan Ajar Siswa SMK N 11 Semarang. Unnes Science Education Journal. 2(2): 245-253.

Nieveen, N., McKenney, S., \& Akker, J. V. 2006. Educational design research: the value of variety. In : Van den Akker, J., Grevemeijer, K, McKenney, S. \&Nieveen, N. Educational design research. London: Routledge.

Hake, R. R. 198. Interactive-engagment versus traditional method: a sixthousand-student survey of mechanics test data for introductory physics courses. American Journal pf Physics.

66(1):64-67 